\title{
«РЕСПУБЛИКА КОСОВО»: НАРКОТЕРРОР РЕГИОНАЛЬНОГО И ГЛОБАЛЬНОГО УРОВНЯ
}

\author{
А. И. Филимонова, С. А. Чередниченко \\ Московский гуманитарный университет
}

Аннотация: Статья посвящена анализу проблем провозглашения так называемой Республики Косово, в жизни которой значительное место имеет деятельность албанских наркокриминальных структур.

Ключевые слова: Косово; Метохия; Республика Косова; терроризм; наркоторговля; албанский вопрос

\section{“THE REPUBLIC OF KOSOVO": NARCOTERRORISM AT THE REGIONAL AND GLOBAL LEVEL}

\author{
A. I. Filimonova, S. A. Cherednichenko \\ Moscow University for the Humanities
}

Аннотация: The paper is dedicated to the analysis of the problems of proclamation of the so-called Republic of Kosovo, in whose life the activity of Albanian drug cartels takes considerable place.

Keywords: Kosovo; Metohija; Republic of Kosovo; terrorism; drug trafficking; Albanian issue

Албанский вопрос перед европейскими правительствами был поставлен на Берлинском конгрессе 1878 г., основной целью которого являлось воспрепятствование расширению российского влияния на Балканах. Главным победителем на конгрессе стала Австро-Венгрия, под покровительство которой перешли православные балканские народы. Одновременно с этого момента ведет отсчет особый интерес, проявляемы Веной к албанскому фактору. На Берлинском конгрессе был представлен Меморандум Призренской лиги, в котором от великих держав требовалось признание албанского национального идентитета и автономии в рамках Османской империи. Это был первый манифест о создании «Великой Албании», который стал платформой деятельности албанских националистов, основанный на идее албанского экспанси- 
онизма и панисламизма. Гарантом реализации требований Меморандума, означающих в перспективе создание независимого албанского государства, указывалась Великобритания - наиболее заинтересованная сторона в установлении барьера «славянской экспансии», которым стала бы независимая Албания.

Главной стратегической целью для Сербии в Первой балканской войне (8 октября 1912 - 30 мая 1913 гг.) являлось получение выхода к Адриатическому морю. Однако содержание Лондонского мирного договора (30 мая 1913 г.) зафиксировало положение, при котором самые большие потери по сравнению с остальными христианскими государствами - членами союза против Порты в аспекте раздела возвращенных территорий нес главный победитель в войне - Сербия. Лондонский мир, при заключении которого роль великих держав являлась ключевой, во-первых, установил новые границы между балканскими союзниками с одной, и Оттоманской империей, с другой стороны, во-вторых, создал албанское государство. На последнем пункте особенно настаивала Австро-Венгрия, которая зашла настолько далеко, что требовала присоединения к независимой Албании Призрена ${ }^{1}$ и Печи ${ }^{2}$, л лишь вмешательство России вынудило передать их Сербии. Так с конца XIX в. - начала $\mathrm{XX}$ в. албанское государство не стало результатом автохтонного развития албанской национальной идеологии и национально-освободительного движения, но явилась итогом балканской политики великих держав, прежде всего, Австро-Венгрии и Великобритании, для которых формирование албанского государства и албанской нации являлись антитезой российскому влиянию в геополитическом и «антинацией» сербам в национальном аспектах.

В составе Сербии и Черногории, затем в югославском государстве экспансия албанского этнического корпуса сопровождалась насилием против сербского населения, терроризмом, террором и криминалом как средством осуществления политических целей, которые достигают пика в период военной агрессии НАТО против СРЮ. Этническая гомогенизация албанцев завершилась в 2008 г. нелегитимным провозглашением на территории Автономного края Косово и Метохии Республики Сербии независимой «Республики Косовы». Однако проект не останавливается на данном этапе, он подразумевает создание этнически чистой «Великой Албании» с Косовом как государственно-политическим центром территорий Балканского полуострова, населенных албанцами и генератором выработки всего арсенала средств в осуществлении цели.

\footnotetext{
${ }^{1}$ Призрен - столица средневекового сербского государства в период правления царей Душана и Уроша, получивший народное название «сербский Царьград».

${ }^{2}$ Печ - исторический центр Сербской Православной церкви, центр Сербской архиепископии с 1253 г., с 1356 г. - Печская патриархия.
} 
Научные труды Московского гуманитарного университета 2019 № 2

В конце 1990-х гг. для реализации албанских сепаратистских устремлений на территории Косово и Метохии послужили паравоенные формирования карательно-диверсионного характера, главным из которых была Армия освобождения Косово (АОК, УЧК - Ushtria Çlirimtare e Kosovës, от алб. UС̧К). Фактически АОК была сформирована в 1993 г. в районе Дреница (центральная часть Косово к западу от Приштины) на конференции общего совета т. н. Народного движения Косово (НДК), во главе армии стали Хашим Тачи и Джеват Халити. Относительно Халити уже тогда были известны его близкие связи спецслужбой Албании «Сигурими». Официальное создание Армии освобождения Косово стало отправной точкой терминальной фазы террористической борьбы за насильственное отделение Косово от Сербии. В состав Главного штаба АОК в разные периоды входили в следующем качестве: глава Генштаба Агим Чеку, главнокомандующий Сулейман Селеми, глава Отдела по логистике Джеват Халити, глава Отдела по венным операциям Реджеп Салими, глава разведслужбы Кадри Весели, глава Отдел информации, позднее переформированного в Отдел по политическим вопросам Хашим Тачи, начальник Управления полиции Фатмир Лимай.

Спецификой деятельности АОК являлось сращение террористической и криминальной активности. Главари АОК одновременно являлись лидерами криминальных группировок, «ответственных» за определенные зоны на территории Косово, действующих по сей день и поддерживающих экстремально высокий уровень деструктивного потенциала не только в балканском, но и европейском регионе. Криминальные силы в Косово приобрели настолько мощный размах, что, как отмечает известный французский криминолог Жан-Франсуа Гейро, «работает почти совершенная лаборатория создания девиантных государств как части криминального корпуса новой Европы» ${ }^{\text {. }}$ Средства криминальных группировок от торговли наркотиками, оружием и людьми являлись самым надежным способом финансирования АОК и албанского сепаратизма.

Основным средством дохода «Республики Косовы» является наркотрафик. Его возникновение и развитие относится к завершающему этапу существованию СФРЮ. Тогда, в начала 1980-х гг., албанская контрабанда наркотиков осуществлялась по маршруту из Ближнего Востока через Балканы в Европу и США, и проявлялась лишь спорадически. В тот период албанцы были лишь курьерами, наемниками преимущественно у турецкой наркомафии и болгарских криминальных структур. Однако по мере роста албанского сепаратизма в Космете, расширения влияния албанских эмигрантских групп и особенно поддержки со стороны внешнего фактора начали оформляться

${ }^{1}$ http://www.vesti-online.com/Vesti/Hronika/233286/Kriminalci-vladaju-Balkanom- 
самостоятельные албанские наркомафиозные структуры. Коренное изменение статуса албанских наркокланов произошло в конце 1990-х гг., когда Госдеп США приступил к реализации своих многоуровневых геостратегических целей на Балканах, одним из инструментов достижения которых были избраны албанские криминальные группировки. Помощь албанскому сепаратизму была оказана всесторонняя: дипломатическая, экономическая, военная (вплоть до нанесения воздушно-бомбовых ударов по СРЮ), албанскому криминалу был предоставлен карт-бланш на деятельность как на Балканах, так и в Европе. Американская разведка ДЕА весной 1999 г. приводила сведения, что группы косовских албанцев, «ответственные» за транспортировку наркотиков, находятся на втором месте на балканском маршруте, сразу после турецких ${ }^{1}$.

В настоящий момент албанские наркокриминальные структуры уверенно движутся в направлении усиления своего влияния в разных государствах региона и мира. Различные организации по борьбе с организованной преступностью - FBI, Интерпол и Европол - свидетельствуют, что албанская мафия стала самой серьезной криминальной организацией в Европе, поскольку контролирует большую часть торговли героином во многих европейских странах.

Балканские наркокоридоры подразделяются на два главных потока: северный героиновый («золотой полумесяц» Афганистан-Пакистан, далее Турция - Венгрия - Румыния) и южный кокаиновый (Турция - Греция Македония - Албания - Италия). Центром «Балканского маршрута» является Косово и Метохия. По различным оценкам, в настоящий момент албанская мафия контролирует около 75\% процентов героина, поступающего на западноевропейский наркорынок и до половины совокупного количества героина, продаваемого в США. За поставки героина в Европу отвечают около 30 албанских наркокланов, каждый из которых контролирует «свой» участок наркотрафика. В такой наркотрафик превращена почти вся территория Косово (за исключением четырех северных общин - Зубин Поток, Звечан, Лепосавич, северная Косовская Митровица, населенных сербами). Албанские кланы в Космете ежемесячно осуществляют оборот героина в размере от 4 до 6 тонн, стоимость годового оборота только героина -2 млрд. долларов. Деньги от наркоторговли отмываются посредством более двухсот частных банков, а также через сеть салонов красоты, парфюмерных магазинов, кафе и т. п., открытых в Италии, Испании, Великобритании и в других странах Западной Европы.

${ }^{1}$ http://www.novosti.rs/вести/насловна/досије.407.html:311914-Marti-zavrteo-itockove-istrage 
Научные труды Московского гуманитарного университета 2019 № 2

Канал-трансфер наркотиков из Турции в Италию проходит через Тропой, порты Дуррес и Валону (Албания). В Албании также находятся лаборатории по переработке сырья и производству кокаина и героина, направляемого затем в Лужане, Муховац и Велики Трновац на юге Сербии, а также в Тузы и Ульцинь в Черногории. Крупные центры оборота наркотиков находится в Македонии - Гостивар, Куманово и Скопье. С территории этих трех стран наркотики распространяются по всей Европе. Передача наркотиков, оружия и других контрабандных товаров происходит на официальных пограничных пунктах (главным образом, Тропой), благодаря сотрудничеству преступных групп с персоналом таможни.

Преступная деятельность в КиМ осуществляется семейными кланами фисами, каждый из которых контролирует определенную часть территории Космета. Сферы влияния поделены на три основные зоны: Дреница, Дукаджин и Лаб, в которых лидерами преступной активности являются бывшие полевые командиры АОК, в настоящий момент действующие главы наркокриминальных фисов и ключевые политические фигуры «Республики Косовы».

Так, контролем стратегической дороги, соединяющей Черногорию и Македонию через Призрен, Клину и Исток, занимается Дреницкая группировка во главе с Хашимом Тачи (бывший лидер Демократической партии Косово, передавший свой пост Кадри Весели после победы на президентских выбоpax в 2019 г., ныне пятый президент «Республики Косовы»). Группа занимается незаконной продажей наркотиков, оружия, сигарет, крадеными автомобилями, топливом, а также торговлей «белыми рабами», т.е. людьми. Семья Тачи тесно связана с албанской, македонской, болгарской и чешской мафией. В данном районе «работают» также фисы Лука и Селими, занимающиеся всевозможной контрабандой.

В настоящий момент в состав Дреницкой группировки, помимо Тачи, входят не менее печально известные личности в Косово, ныне занимающие весьма солидные посты: председатель «косовского парламента» Кадри Весели, «вице-премьер косовского правительства» и глава переговорной группы по линии Приштина-Белград Фатмир Лимай и один из руководителей албанской разведки K-SHIK Джеват Халити. Спецдокладчик Совета Европы Дик Марти в своем докладе, посвященном организованной преступности в Косово (Marty, 2010: Электр. pесурс), приводит данные о том, что члены Дреницкой группы Джавит Халити, Кадри Весели, Азем Суля, Хашим Тачи и Фатмир Лимай были непосредственно вовлечены, а в ряде случаев лично приказывали и контролировали убийства, похищения и пытки в различных частях Косово в период с 1998 по 2000 гг. Аналитики стран НАТО пришли к выводу о том, что за мощным криминалом в Косово стоит Хашим Тачи. Именно Тачи в докладах спецслужб Германии (БНД), Италии (СИСМИ), Великобритании (МИ-6), Гре- 
ции (ЭЙП) назван наиболее опасным главарем мафии и командиром АОК. Дик Марти указывает: связи Тачи с организованным криминалом начались задолго до начала горячей фазы конфликта в Косово, а Дреницкая группа постепенно поставила под свой контроль остальные группировки тогда разрозненного сепаратистского движения, с 1998 г. она становится головной организацией для большинства ОПГ Албании, членами которых были косовские албанцы. В течение последующего за конфликтом десятилетия Тачи и члены его Дреницкой группы установили жесткий контроль над героиновым наркотрафиком и торговлей другими наркотиками (там же: 15, Электр. ресурс).

На территории Печи, Дечан и Чаковицы, расположенных в районе Дукаджин, действует так называемая Метохийская группа под руководством Рамуша Харадиная (лидер Альянса за будущее Косово, премьер-министр «Республики Косово»). Семья Харадинай также занимается незаконным оборотом наркотиков, оружия, акцизными товарами, крадеными транспортными средствами, а также вымогательством у албанского населения в КиМ. Контрабандный товар переправляется в Македонию, южную Сербию и Черногорию по дороге Печ-Кула-Рожае. Благодаря тесной связи Рамуша с бывшими командирами АОК, которые после демилитаризации были переведены в Корпус защиты Косово (КЗК, с 1999 по 2009 гг., с 2009 по 2018 гг. - Силы безопасности Косово, с 2018 - Армия Республики Косово) и Косовские полицейские силы (КПС), осуществляется по-военному четкая переброска контрабанды. В данном регионе также «работает» фис Келменди, в районе Чаковицы особенно активен клан Бабалия, сотрудничающий с кланом Харадинай.

На территории Лаба, включая Гнилане, Витину и Качаник, существует «группа Реми» под руководством Рустема Мустафы (бывший лидер АОК, был осужден и приговорен к нескольким годам лишения свободы), тесно связанного с семьей Харадинай. Клан Сума, связанный с «группой Реми», работает в Качаницком районе. В дополнение рэкету и шантажу, он занимается контрабандой оружия и наркотиков из Македонии в КиМ и в обратном направлении.

Помимо наркотрафика, на территории КиМ также зафиксирована незаконная торговля оружием, акцизными товарами, украденными автомобилями, контрабанда рабов и «черная трансплантология» - торговля человеческими органами. Рэкет, шантаж и насилие в отношении членов своей же национальной албанской общины в Косово, а также албанцев, занимающихся временной работой за границей, являются «визитной карточкой» организованной преступности. Запугивание и изгнание сербов и другого неалбанского населения с территории КиМ (этнические чистки) также являются легким источником дохода, поскольку от продажи заброшенного жилья и вынужденно продаваемых участков земли (а именно сербам принадлежит подавляющая часть земли в КиМ) поступает огромная прибыль. Бывшие лидеры АОК 
Научные труды Московского гуманитарного университета 2019 № 2

таким образом финансируют независимость и самостоятельность «Республики Косовы».

Кровнородственно-криминальные фисы являются не теневой, а единственной реальной политической и иной властью, обладающей своей спецслужбой K-SHIK, спонсируемой напрямую ЦРУ. Преступный косовский мир тесными семейными узами связан со своими иностранными «коллегами». Кроме того, албанские наркосиндикаты скоординированы с местными квазигосударственными органами и политическими структурами настолько близко, что невозможно провести границу где заканчивается одни и начинаются другие.

Самая большая концентрация криминальных группировок - в Приштине, это кланы Мустафа, Реми, Келменди, Лука, Халити, Рамадани, Шабанай, Марай, Мальоку и Гецай-Селими. Однако в компетенцию каждого клана могут входить и несколько зон - это семьи Лука, Реми, Гецай и Селими. Совпадение зон ответственности фисов и прежних зон ответственности АОК показывает, что последняя выпестовалась из существующих организованных групп, после формального роспуска с прибытием международных сил она вновь влилась в состав криминальных формирований.

В настоящий момент Хашим Тачи является ключевым рычагом для решения политических задач. Однако в определенной степени антитезой ему является более авторитетный с организационной и военной точки зрения Рамуш Харадинай. Разница между ними заключается в том, что Тачи склонен к определенным компромиссам ради удержания власти, постепенно он превращается в политического «белого воротничка», в то время как Харадинай представляет традиционную непреклонную албанскую националистическую линию. Тачи контролирует более широкую и мощную криминальную сеть на большей части Косово (в основном по линии Приштина-Глоговац-Србица-Клина-Ораховац-Призрен). Рамуша Харадиная - с албанской точки зрения «прокаленного в боях командира» - поддерживает подавляющее большинство бывших командиров АОК (значительная часть которых так или иначе оказалась в составе созданной в обход Резолюции СБ ООН 1244 «Армии Косово»), финансовую помощь ему оказывает клан Лука из Печи, что позволяет ему контролировать направление Печ-Дечани-Джаковица. Однако и Тачи, и Харадинай одновременно являются фаворитами крупнейшего наркобосса Джавита Халити, а также международных факторов и структур в Косово (KFOR, UNMIK, EULEKS) и, по сути, в нужные моменты разыгрывают роли «хорошего» и «плохого» полицейского в отношении Сербии, целью игры остается константа: признание «Республики Косово» со стороны Сербии и получение членства в ООН. 
Отношения между фисами регулируются обычным правом, восходящем к Закону Леки Дукаджини (XV век), включающим, помимо прочего, кровную месть, и «кодекс мафии», прежде всего, омерту. При этом позитивные нормы закона рассматриваются как секундарные, т.е. неважные и необязательные. Основное правило всех кланов - кровная месть в случае предательства. Пункт Закона Леки Дукаджини был включен в присягу АОК: «... Если нарушу присягу, пусть меня накажут самой строгой законной военной казнью мерой, а если совершу предательство, пусть прольется моя кровь. Клянусь» (Албански ... , 2003).

Особенно тесное сотрудничество албанские фисы поддерживают с зарубежными группировками из Турции, Албании, Болгарии, Македонии, поскольку по территории этих стран продолжаются транзитные наркопути.

Внутриклановые отношения характеризуются чрезвычайно строгой иерархией и дисциплиной, которая достигается с помощью системы наказаний за любое отклонение от обычаев и правил, страх от неотвратимого наказания гарантирует безоговорочную лояльность. Поскольку фисы строго привязаны к определенной территории и основаны на кровном родстве, это ограничивает число его членов и исключает возможность оперативного внедрения агентов спецслужб и полиции. Как правило, главари кланов способны к достижению быстрых и гибких договоренностей с криминальными организациями или представителями других стран, однако в «бизнес» фиса члены других национальных группировок допускаются только как исполнители одноразовых и второстепенных задач. В целом криминальная иерархия мафиозных семей включает, как правило, 3-4 уровня, так что даже при нейтрализации одного или нескольких глав клан продолжит эффективно функционировать. Организация подобного рода позволяет албанским криминальным группам планировать и осуществлять масштабные и сложные операции во всех областях «делового интереса» и при использовании военного опыта из войн прошлых лет и оперативного - из деятельности собственных и албанских спецслужб, а также современных технологий и средств. Кроме того, поскольку у косовских албанцев очень сильно развита коллективная идентичность, основанная на коллективной принадлежности, данный сегмент самосознания способствует связи организованного криминала с идеями паналбанизма, панисламизма и террористической деятельностью.

Несмотря на то, что кланы стратифицировали территории по зонам своей ответственности, периодически между ними возникают конфликты, основанные на политической и конкурентной почве. Иногда подобные конфликты приводят к масштабной кровной мести, которая распространяется на всех членов враждующих семей. Например, ссора между семьями Мусай и 
Харадинай, возникшая в результате попытки семьи Мусай перехватить под свой контроль часть «бизнеса» Харадинаев, привел сначала к убийству Синана Мусая, ранению Рамуша Харадиная, а позднее - к полному истреблению клана Мусай. Столь непримиримая жестокость борьбы в первую очередь обусловливается огромной прибылью от наркопотока.

В целом на территории бывшего автономного края Косово и Метохия, объявленного сепаратистами «Республикой Косова» (кроме сербского севера), деградировало все, кроме процветающей организованной преступности. Экстремистские группы АОК ликвидировали всех своих политических противников, заставляя собственное албанское население жить в атмосфере постоянного страха. Представители Совета Европы регулярно сообщают о зашкаливающем уровне коррупции, отмывании денег, экономических преступлениях, неэффективности финансовых учреждений и налоговой политики. Косовские суды не отвечают современным требованиям, число судей и прокуроров невелико, заработная плата недостаточна для обеспечения их независимости, суд находится под сильным политическим давлением, даже личная безопасность персонала судебной системы не может быть гарантирована. Организованный криминал превратился в теневое, но реальное правительство.

За спиной у албанских наркокланов в Косово и Метохии - две американские военные базы «Бондстил» и «Малый Бондстил», а также полный комплекс поддержки со стороны США и Евросоюза - от дипломатической до масс-медийной и военной. США сыграли решающую роль в начале вооруженной агрессии НАТО 1999 г. на стороне косовских сепаратистов, целью, как образно отмечает в бытность свою немецкий депутат, госсекретарь и вице-президент Парламентской ассамблеи ОБСЕ Вили Вимер, еще в 1980-х гг. ставилось «создание независимого Косово в качестве сухопутного авианосца США», стремившихся к доминированию на Балканах ${ }^{1}$.

Тачи, Халити, Весели, Суля, Лимай за последние годы подвергались судебным преследованиям за военные преступления или участие в совместном преступном деянии, расследование вели Международный трибунал по бывшей Югославии, Администрация ООН по Косову (УНМИК), Европейская миссия права в Косово (ЕУЛЕКС). Однако вместо тюремного заключения главари АОК и наркомафии на свободе, более того, и поныне являются ключевыми общественными и политическими фигурами. Хотя в Космете общеизвестен факт: избежать суда им удалось благодаря запугиванию и физическому устранению свидетелей и нежелание «международной общественности» наказывать тех, кто является экспонентом их политики и кого они поддерживают по сей день.

\footnotetext{
${ }^{1}$ https://srpskistav.com/prenosimo/вили-вимер-косово-као-држава-планиран /
} 
После Косово удар нацелен на юг Сербии (общины Прешево, Буяновац, Медвежья с большинством или значительной частью албанского населения) с перспективой получения контроля над стратегическим направлением, связующем Космет, Македонию, Сербию и Болгарию с выходом на Грецию и Центральную Европу. Одним из главных дистрибьютивных центров всего Балканского полуострова является село Велики Трновац (община Буяновац, на административной границе с Косово, население - около 10 тыс. человек, исключительно албанцы). Велики Трновац находится также вблизи от границ с Болгарией, Албанией и Македонией и он - настоящий «перекресток наркомагистралей». Через него идет героиновый поток из Афганистана, Пакистана, Ирана и Турции. Здесь находятся склады и идет упаковка «товара». По некоторым оценкам, ежегодный оборот наркотических веществ, осуществляемый через Трновац, составляет около 50-60 тонн героина, который через Албанию и Черногорию поступает в Италию, частично оседает в Сербии и далее поступает в другие западноевропейские страны.

Велики Трновац недаром называют «героиновыми воротами Запада». В процесс дистрибьюции героина вовлечено все население (албанское) региона - около 6 тыс. человек. Интерпол отмечал, что там постоянно готово к продаже по меньшей мере три тонны героина. Итальянский Центр по борьбе с мафией указывал, что 70\% наркотиков, предназначенных для западноевропейского рынка, идет через Прешево и Великий Трновац, а весь процесс контрабанды контролируют семейные кланы Османи, Халифи и Буньаку. Итальянцы отмечали, что регион крайне криминализирован, а сербские власти адекватно ситуации не реагируют. При этом сами сербские полицейские отмечают особые трудности, связанные с пресечением преступной деятельности, связанной с наркобизнесом. В нем действуют исключительно семейно-клановые связи, поэтому внедрение или инсайдерская информация практически невозможны. Организация поставлена настолько «хорошо», что полиции даже приблизиться к Велики Трновцу представляет проблему .

Западную часть Македонии и часть Косово контролирует клан Тачи, Мендух Тачи, председатель македонской Демократической партии албанцев, непосредственно связан с мафией, контролирующей такие сферы, как товарооборот героина, кокаина и автомобилей. В Македонии около Куманово находится и одна из крупнейших фабрик по производству героина. В Албании наиболее влиятелен клан Бериша, он «охватывает» и часть Метохии. Не меньшую опасность представляет собой наркоклан семейства Кула, контролирующий наркооборот из Турции, поставки оружие и нелегальных мигрантов; клан Абазии (наркотики и проституция в «сотрудничестве» с итальянским криминалом); Брокай (его основу составляют бывшие работники спецслужб и политики, их «сфера» - наркотики, оружие, проституция). По сути, весь ре- 
Научные труды Московского гуманитарного университета 2019 № 2

гион - Албания, Косово и Западная Македония — является одним большим наркоскладом.

Около 80\% венгерского рынка героина также находятся в руках албанской мафии, продает она в основном также героин из Турции и Афганистана. По данным словацкой полиции, почти $100 \%$ героина в Словакию поступает из Афганистана «балканским трафиком» через Косово, Македонию и Албанию. В последнее время албанские группировки прибирают к рукам порты Румынии. Основная прибыль от наркобизнеса идет для «Республики Косовы», при этом большая часть денег тратится в Италии, где закупается оружие. В Италии за краткое время албанской наркомафии удалось потеснить турецкую. Из курьеров албанцы стали организаторами наркосети и партнерами сицилианской Koza nostra, неапольской Kamori и калабрийской N'dragenti. Италия является одной из главных опорных баз албанских криминальных структур, через руки которых проходит около 50 кг героина ежедневно. Милан - это «бизнес-центр», но область Калабрия - центр торговли нарктиками и оружием. На границе Италии и Швейцарии наркотрафик контролируют албанцы.

Не менее важным «опорным пунктом» в Европе является Швейцария отсюда начиная с конца 1990-х гг. финансировалась «балканская смерть»террористические албанские армии. Центр «черной биржи» торговли оружием находится в Берне и Базеле. В Швейцарии особо известен клан Османи, главарь которого - Чазим («Феликс»). Помимо доходов от наркотрафика, работорговли и остальных видов организованной преступности, клан пользуется финансовой поддержкой крупнейшего албанского «бизнесмена» из Косово Беджета Паццоли.

В Швеции и Норвегии албанцы контролируют 80\% наркоторговли, албанцы из Косово уже десять лет остаются главными дестрибьютерами на греческом рынке кокаина, героина и марихуаны. Греческий трансфер албанцы используют для поставок мигрантов-албанцев и нелегалов из Турции, Пакистана, Шри-Ланки, Китая и т. д., которые также являются курьерами по доставке наркотиков. Таким же коридором является Адриатическое море, связующее побережья Италии и Албании. Методы, применяемые албанскими наркокриминальными группировками, крайне агрессивны, это олицетворение «криминала воинствующего», превращаясь в ночной кошмар полицейских подразделений любой страны.

В феврале 2019 г. британская газета «Miror» приводит сведения о том, что косовско-албанская (шиптарская) мафия взяла под свой полный контроль рынок кокаина в Великобритании. «Успеху» албанской наркомафии в первую очередь способствовала миграция албанцев после падения коммунистического режима в Албании в 1990 г., которые усилили существующие к тому времени албанские ОПГ в «Туманном Альбионе», отбросили посред- 
ников и установили прямую связь с колумбийскими наркокартелями. Это позволило снизить цену и увеличить «чистоту товара», тем самым вовлекая в наркозависимость все более широкие слои английской молодежи. Кроме того, албанская наркомафия оказывает сильное влияние на другие ОПГ в Великобритании, и связаны с группировками, специализирующимися на отмывании денег и торговле людьми . Тем самым Великобритания, с XIX в. осуществляющая политику ослабления сербских самостоятельных государств на Балканах, видя в них «оружие России», в конце XX - начале XXI вв. представляя всемерную поддержку косовскому сепаратизму, сама столкнулась с угрозой безопасности, на ликвидацию которую ей потребуется бросить все силы, но при совершенно неизвестном исходе.

Так разрешение косовского кризиса путем агрессии НАТО против Югославии под предлогом «гуманитарных соображений» или же «мер по принуждению к миру», дало свои весьма специфические плоды. Истинным победителем стали не албанцы, не международное сообщество, а криминал, исламизм и терроризм. Наркосиндикаты празднуют триумфальную победу и экстремальную выгоду. Албанские наркокланы утвердились на региональном балканском уровне и вышли далеко за его пределы. Для США, Евросоюза, а также для Российской Федерации деятельность албанских наркокриминальных групп являет собой угрозу, подрывающую основы национальной безопасности.

\section{СПИСОК ЛИТЕРАТУРЫ}

Албански тероризам и организовани криминал на Косову и Метохији. Влада Републике Србије (2003). Београд.

Marty, M. (2010) Inhuman treatment of people and illicit trafficking in human organs in Kosovo [Электронный ресурс] // Committee on Legal Affairs and Human Rights. AS/Jur. December. URL: https://assembly.coe.int/CommitteeDocs/2010/ ajdoc462010prov.pdf (дата обращения: 12.03.2019).

Дата поступления: 16.03.2019 2.

Филимонова Анна Игоревна - кандидат исторических наук, доцент кафедры международных отношений и дипломатии факультета международных отношений и туризма Московского гуманитарного университета. Адрес: 111395, Россия, г. Москва, ул. Юности, д. 5. Тел.: +7 (499) 374-75-31. Эл. адрес: Intrelation@mosgu.ru 
Чередниченко Сергей Александрович - студент кафедры международных отношений и дипломатии факультета международных отношений и туризма Московского гуманитарного университета. Адрес: 111395, Россия, г. Москва, ул. Юности, д. 5. Тел.: +7 (499) 374-75-31. Эл. адрес: Intrelation@ mosgu.ru

Filimonova Anna Igorevna, Candidate of History, Associate Professor, Department of International Relations and Diplomacy, Faculty of International Relations and Tourism, Moscow University for the Humanities. Postal address: 5, Yunosti St., Moscow, Russian Federation, 111395. Tel.: +7 (499) 374-75-31. E-mail: Intrelation@mosgu.ru

Cherednichenko Sergey Aleksandrovich, Student, Department of International Relations and Diplomacy, Faculty of International Relations and Tourism, Moscow University for the Humanities. Postal address: 5, Yunosti St., Moscow, Russian Federation, 111395. Tel.: +7 (499) 374-75-31. E-mail: Intrelation@mosgu. $\mathrm{ru}$

\section{Для цитирования:}

Филимонова А. И., Чередниченко С. А. «Республика Косово»: наркотеррор регионального и глобального уровня [Электронный ресурс] // Научные труды Московского гуманитарного университета. 2019. № 1. URL: http://journals.mosgu.ru/trudy/article/view/959 (дата обращения: дд.мм.гг.). DOI: 10.17805/trudy.2019.2.2 